\title{
Transportation Usage And Characteristics Of Washington State Warehouse/Distribution Center Businesses: A First Look
}

Eric Jessup, (E-mail: eric_Jessup@wsu.edu), Washington State University Ken Casavant, (E-mail: casavantk@wsu.edu), Washington State University Quinton Pike, Washington State University

\begin{abstract}
The paper provides an analysis and overview of the operations of the warehouse/distribution center businesses in the state of Washington, with implications for all national and international distribution businesses.
\end{abstract}

\section{INTRODUCTION}

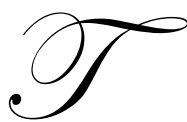

he growing amount of congestion within the state of Washington has prompted concerns regarding the state's ability to appropriately anticipate and provide for freight transportation infrastructure needs. It is estimated that there are 21.6 million truck trips made each year on state highways. Of that 21.6 million, an estimated $45 \%$ of freight transported originated from or is destined for a warehouse or distribution center within the state.

In order to ensure efficient freight mobility, private and public policy makers will need to understand the complex operations and mode capabilities utilized within the Warehouse/ Distribution Center industry. To aid this understanding an understanding of this business sector is useful. The analysis presented in this paper will provide an overview of chokepoints and system deficiencies that occur in various freight corridors throughout the state.

\section{STUDY APPROACH}

The list of survey respondents used for this study was compiled from sources within numerous agencies at the local, county, state, and federal levels. The names and addresses of additional potential respondents were obtained from regional economic development offices, city business license/treasurer departments, and the Washington State Department of Revenue. Additional contacts were generated from industry sources and internet searches.

Significant effort was taken to obtain data that would yield a sample representative of the industry. To insure that the data were reliable and accurate, the list was contrasted and compared to different extant sources. The list of respondents was validated and checked for accuracy of business name, address, and phone number using various online services including Dun \& Bradstreet, Washington State Department of Revenue and Switchboard.com.

The data collection method chosen for this study was a mail survey. Mail surveys allowed the research team to gather the greatest possible amount of information from the greatest number and widest range of respondents. To encourage a high response rate, the survey consisted of a four step process. These steps included:

- Week One: $1^{\text {st }}$ Mailer and Questionnaire

- Week Two: Postcard

- Week Three: $2^{\text {nd }}$ Mailer and Questionnaire

- Week Four: Phone Call 
The survey was conducted during the period of July $2^{\text {nd }}$ through August $1^{\text {st }}$. Each mailer consisted of a stamped return envelope, questionnaire, and cover letter explaining the purpose of the survey and contact information for if the respondents had any questions.

The questionnaire was divided into four sections to facilitate the collection of a broad range of information. The four sections were Warehouse Operations, Intermodal Systems, International Trade, and Other Transportation Related Issues. The questionnaire was designed to take between 15 and 20 minutes to complete.

\section{GENERAL FINDINGS}

Of the 973 mailers sent, 97 were returned due to incorrect, outdated, or invalid addresses or for nonqualifying recipients. The overall response rate for this study was $29 \%$. This total response rate includes those responses that indicated that the recipient was not interested in participating in the study or did not receive/distribute freight at that facility. A total of 142 companies or $16.2 \%$ of companies who received questionnaires returned useable survey responses.

The useable responses were sorted into six coverage areas based upon accessibility to key highways and their proximity to densely populated regions of the state. The number of survey respondents in each of the six sample coverage areas is indicated in Figure 1.

Figure 1. Warehouse/Distribution Center Sample Coverage Areas

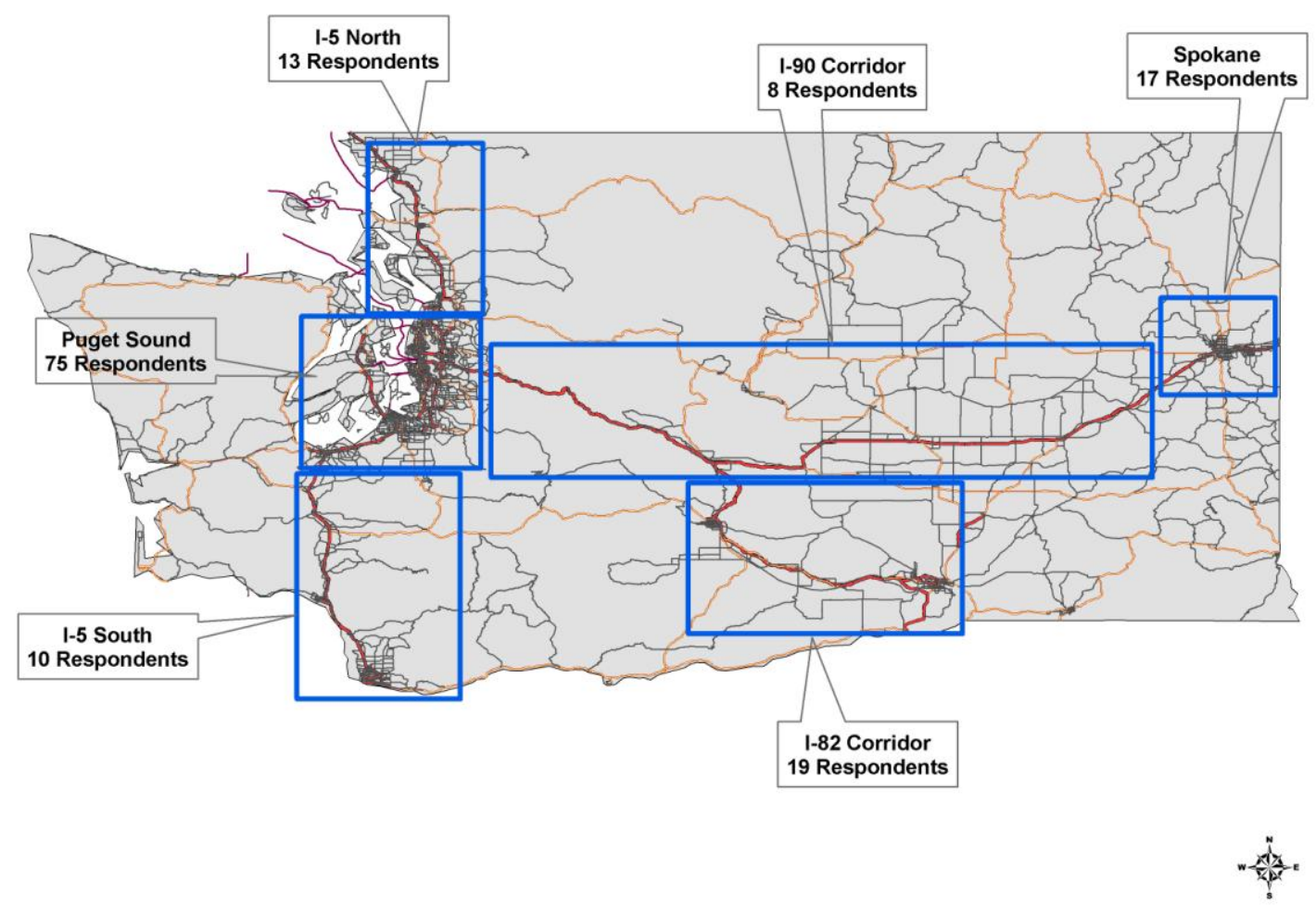

\section{WAREHOUSE OPERATIONS}

A significant amount of information on the basic characteristics and operational procedures of warehouse/distribution centers was captured in the survey questionnaire. Information pertaining to daily/seasonal time distribution of inbound and outbound shipments, average length of haul, and the number of inbound/outbound 
truckloads was collected. This section of the report addresses three key characteristics commonly associated with warehouse/distribution centers: facility size, hours of operation, and type of products handled.

Figure 2. Square Footage of Facilities

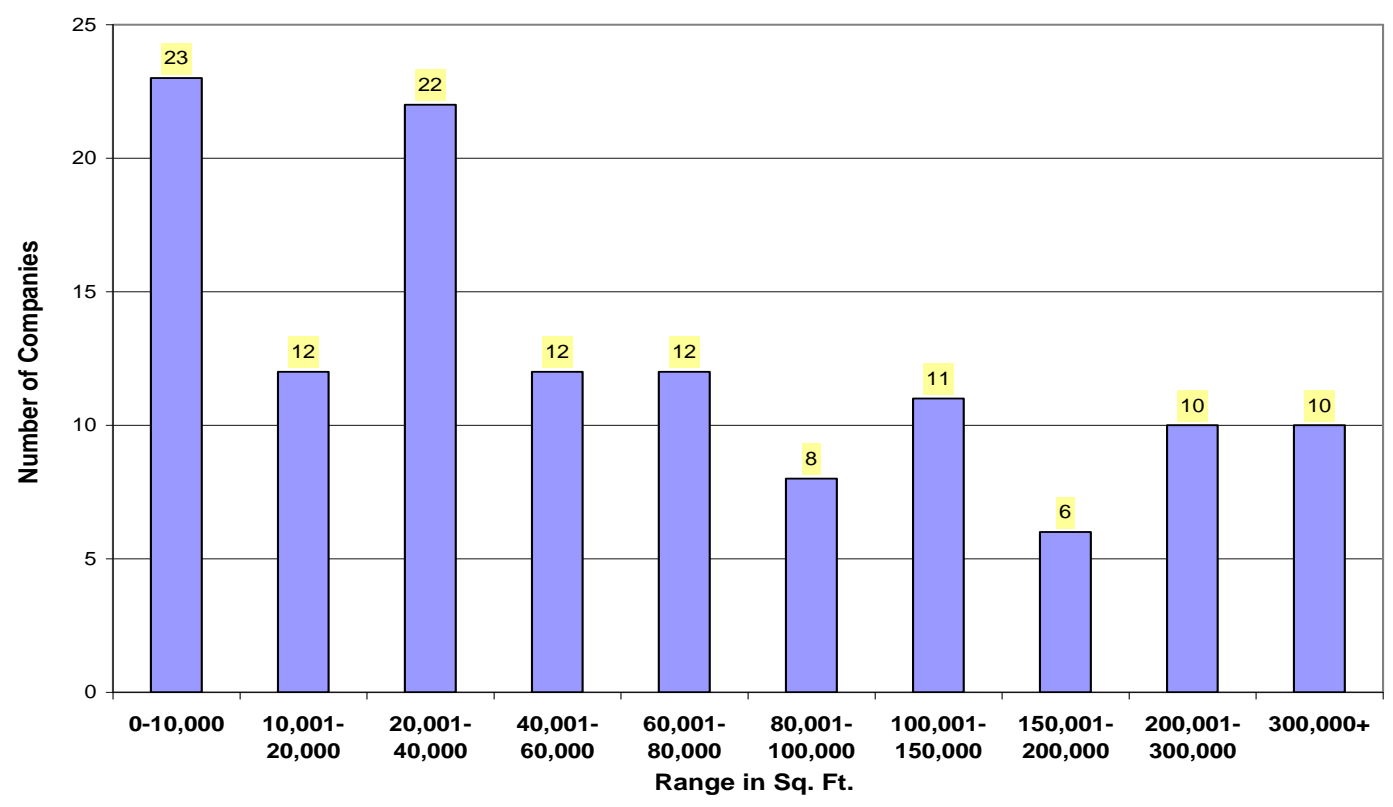

There is a substantial variation in firm size. The number of businesses in various facility size segments, ranging from 0 to 300,000+ square feet, is shown in Figure 2. Facility size for $45 \%$ of the responding firms ranged between 0 and 40,000 square feet. The largest segment, containing 23 firms, fell in the 0 to 10,000 sq. ft. range, followed next by 22 firms in the 20,001 to 40,000 sq. ft. range. The average facility size among all respondents was 118,548 sq. ft., with the median and mode being 50,000 sq. ft. and 10,000 sq. ft. respectively.

In order to understand the traffic pattern associated with the volume of freight that is being moved during the day, respondents were asked to specify at what hours operations were conducted at their facility. The number of companies operating throughout the day is illustrated in Figure 3.

More than two-thirds of companies surveyed operate between the hours of 7:00 AM and 4:00 PM. But, a third of companies begin operations as early as 6:00 AM, with most curtailing operations about 4:00 PM. Most companies are operating during the peak hours of the day when road congestion is typically the greatest. Obviously most companies schedule their delivery times to reach the destination during their customer's hours, typically between 8:00 AM and 5:00 PM. However, there are several companies that do receive and deliver shipments during the low traffic hours of the day.

Companies were asked to specify the types of products received and shipped at their facility since transportation needs and usage is directly affected by the product type. Ten product type categories and the number of companies that distribute them are indicated in figure 4. An 'Others' segment was also included for any products that did not fall under the ten categories. Items listed in the 'Other' category were scrap metal and household goods such as furniture. 
Figure 3. Hours of Operation

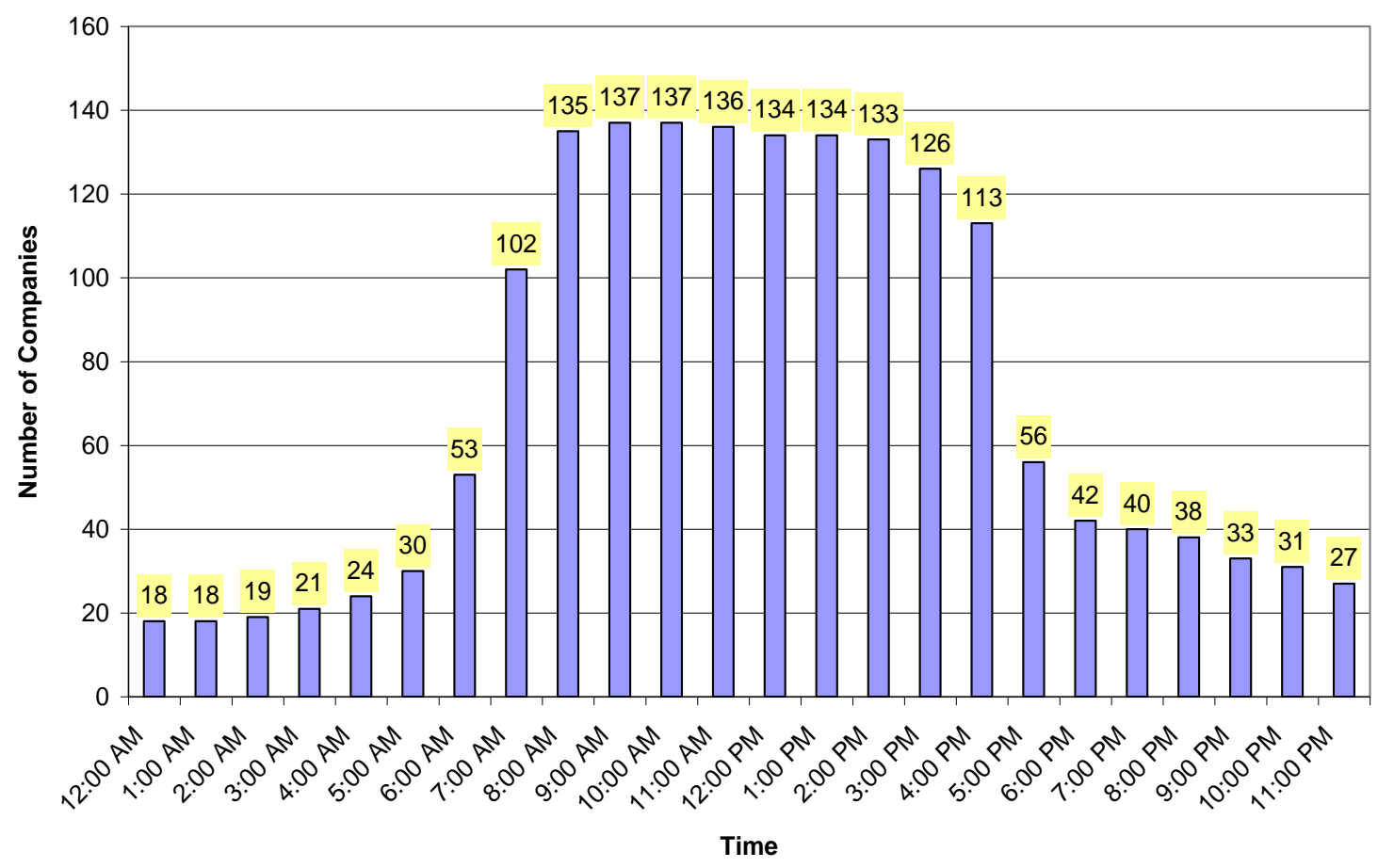

Figure 4. Type of Products Distributed

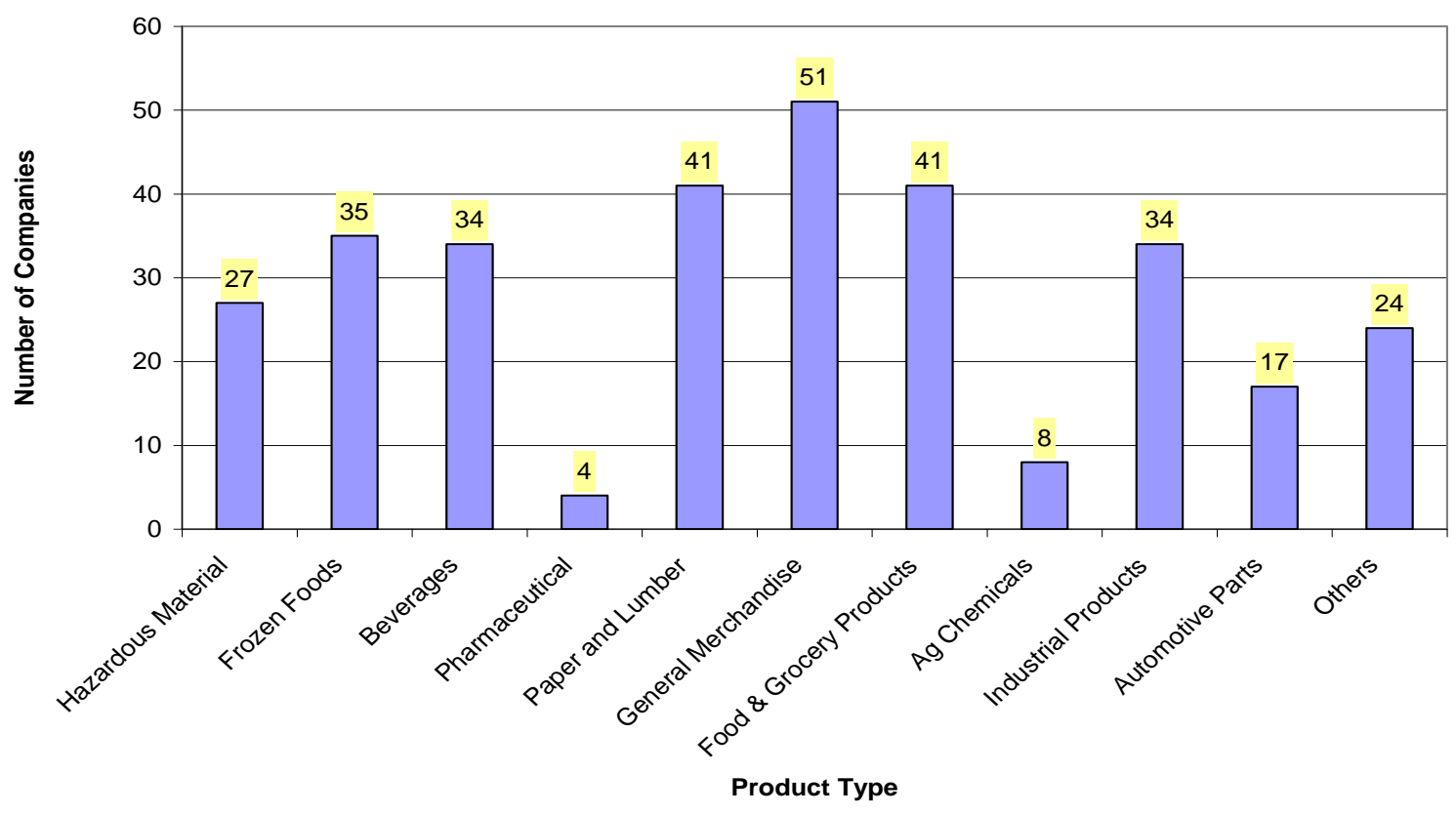


Among the 142 respondents, the General Merchandise category is the most common product type being distributed. This category covered a broad range of products from electronics to apparel. Distribution of other retail goods such as food \&grocery products was also common, accounting for around one third (51 of 142) of all products handled. A substantial number of companies receive and ship paper and lumber related products as well. Nearly one quarter of respondents distributed some form of frozen foods (35) and beverages (34) and about the same number of companies distributed industrial products (34). Twenty-seven companies distribute some form of hazardous material on Washington roadways.

\section{INTERMODAL SYSTEMS}

In order to provide for current and future transportation infrastructure needs, it is vital to recognize the modal services utilized by warehouse/distribution centers in transporting goods in each region of the state.

The percentages of inbound and outbound shipments by transportation mode are sorted by region, and are shown in Figures 5 and 6 . Truck transport remains the primary mode used for inbound and outbound shipments in all six regions. A high percentage of freight movement in western Washington occurs along the I-5 corridor via oceantruck, reflecting the proximity of major international ports. The use of rail-truck is popular in the I-82, I-5 North, and I-5 South regions. Of the six regions, the I-5 South and I-90 regions utilize rail the most in transporting inbound and outbound shipments.

As indicated in Figure 5, the Spokane region had the largest percentage of inbound shipments received via truck. Although the Puget Sound region had the smallest percentage transported only by truck, the area had the biggest proportion of freight being distributed by ocean-truck. The I-5 North region had the largest percentage for barge-truck at $1.7 \%$, followed by Puget Sound with $1.1 \%$. The corridor along I-5 South had the largest percentage of freight coming in on rail at $7.8 \%$. Spokane and I-90 followed close behind with $6.1 \%$ for each. For inbound shipments coming by air, I-5 South led with $2.9 \%$, followed by the Puget Sound region at $2.1 \%$.

For outbound shipments shown in Figure 6, the I-5 South corridor had the smallest percentage of goods being transported by truck alone. However, this same region also had the highest percentage of freight being transported via truck-ocean. The I-5 North region had the largest percentage of outbound shipments occur by truck-rail. The I-90 region had the highest percentage of $6.5 \%$ for outbound freight being transported by rail. The I-5 South region had the largest percentage of outbound shipments move by air with $2.8 \%$, followed by the Puget Sound region at $1.6 \%$.

The Spokane and Puget Sound regions as indicated in Figure 6 were the only areas where outbound truck shipments were greater than inbound truck shipments. The Puget Sound corridor has the greatest difference with $11.9 \%$ more outbound shipments than inbound shipments via truck. The region also ships less than it receives via truck-ocean. There was a slight difference of $1.4 \%$ in the Spokane region for outbound versus inbound shipments via truck. Among the other four regions, I-82 had the greatest difference between inbound shipments and outbound shipments being delivered by truck.

Information was obtained from the survey to identify the routes most frequently used by warehouses and distribution centers to distribute freight. Information provided by respondents was sorted by region and mapped using ArcGIS. Each region map identifies various freight corridors based upon the frequency of heavy, medium, and collector usage of inbound and outbound freight.

As an example, the primary routes in the Puget Sound region of Washington are illustrated in Figure 7. Within this region a majority of freight movement occurs along the major interstates of I-5 and I-405. There is also a significant amount of truck traffic occurring between the two interstates on SR-167 and SR-520. SR-16 between Bremerton and Tacoma and SR-512 between Lakewood and Puyallup are also key corridors with modest freight movement. In addition, survey respondents indicated that a portion of freight is being moved along SR-18 to bypass Seattle and connect to I-90 near Snoqualmie. 
Figure 5. Regional Inbound Shipments By Mode

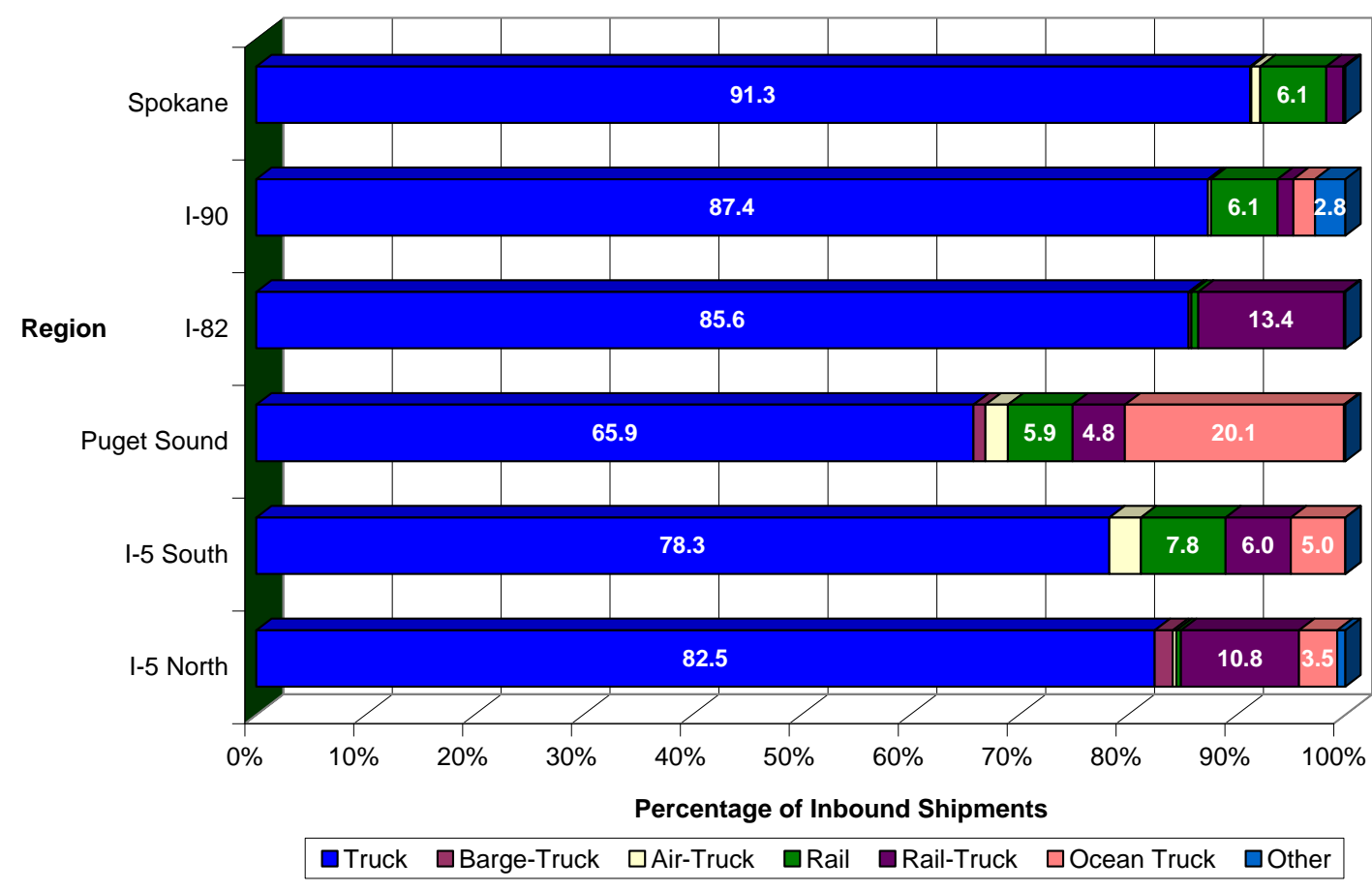

Figure 6. Regional Outbound Shipments By Mode

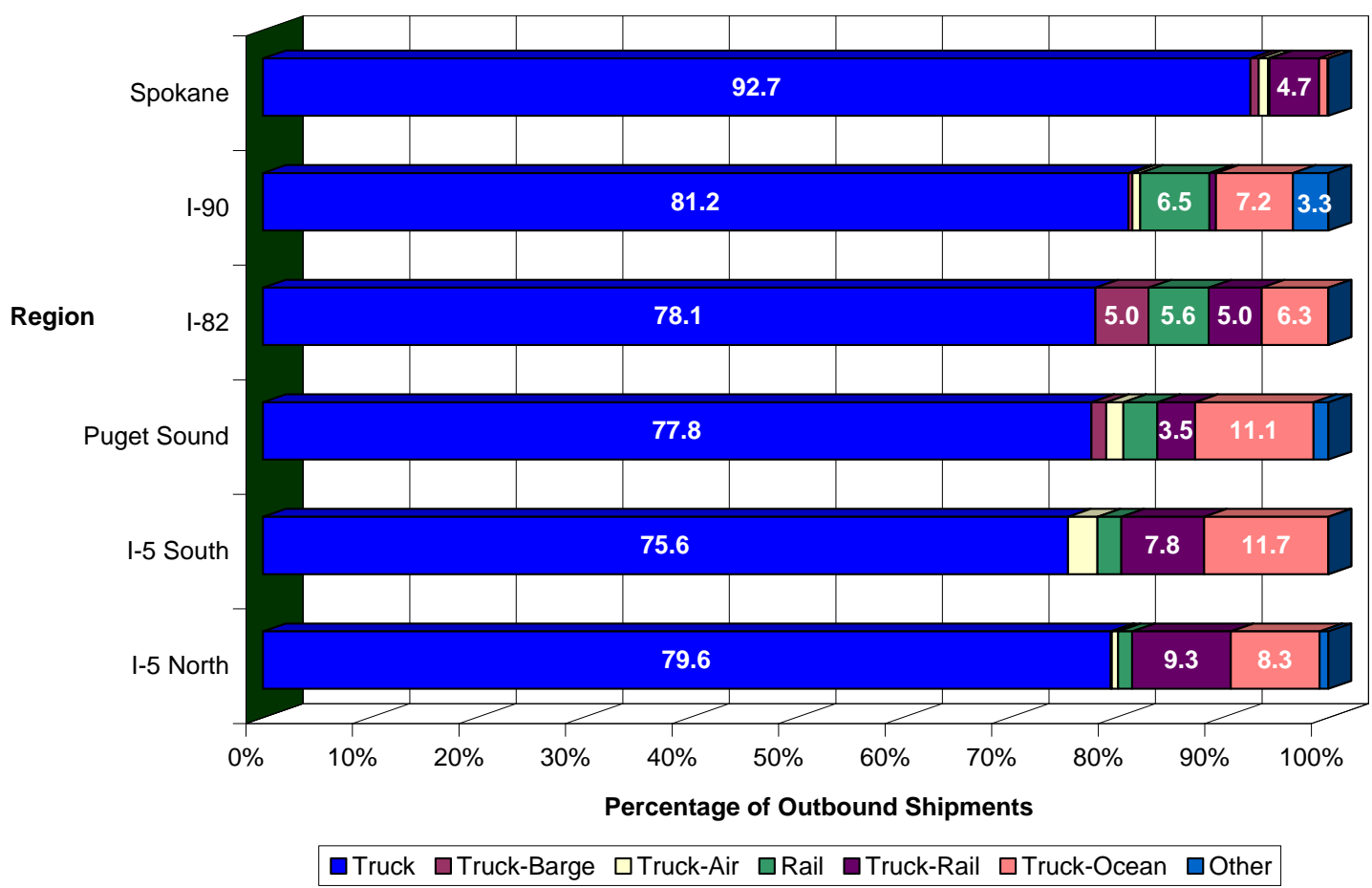


Figure 7. Primary Roads/Highways for Puget Sound Region.

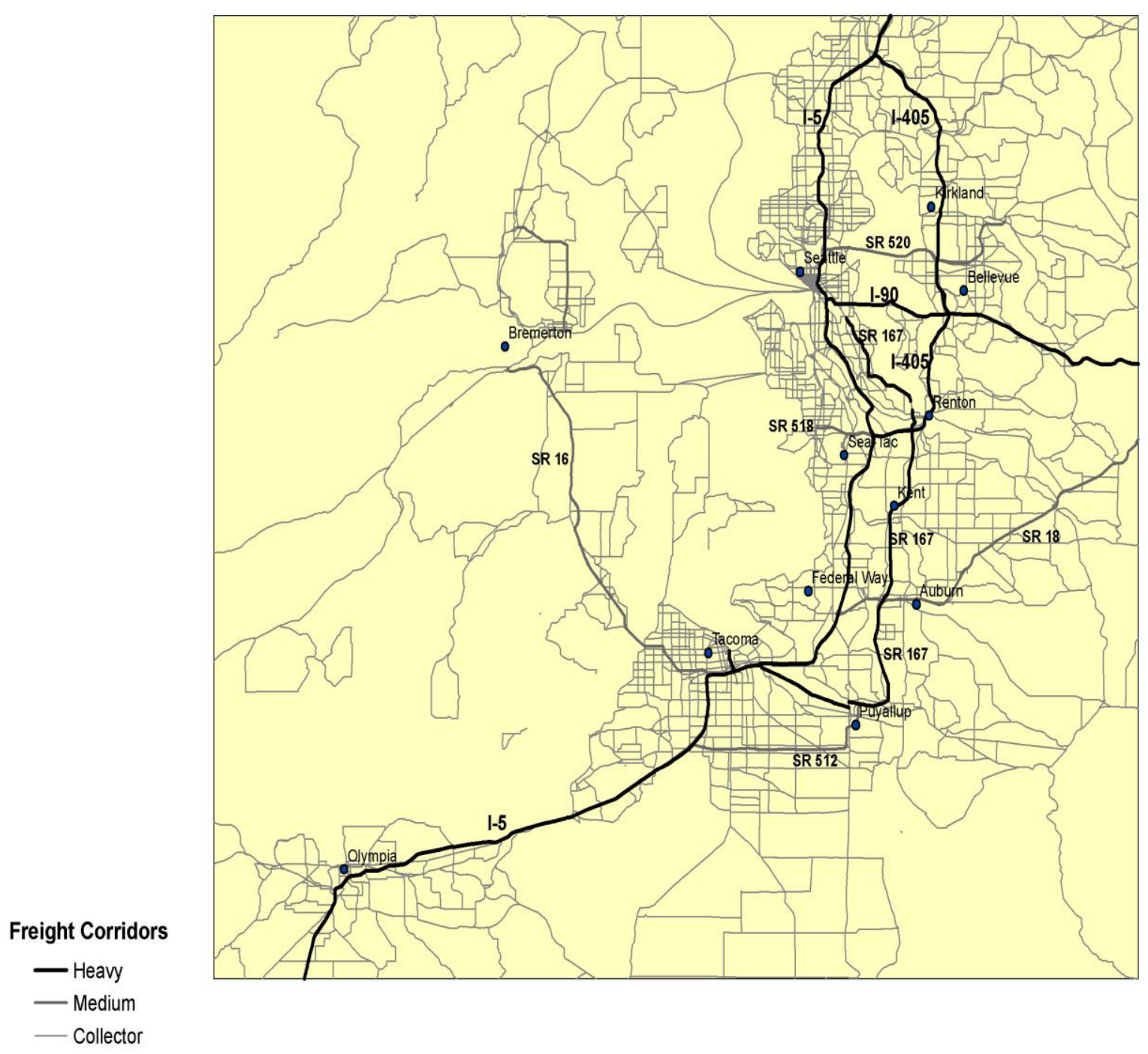

\section{INTERNATIONAL TRADE}

Respondents were asked to identify the country of origin and destination of products handled at their facility. The results are shown in Figure 8. Within the state of Washington, there are generally more warehouses and distribution centers that import than export. Japan was the only country in which exports prevailed over imports. There were also a significant number of companies that import from Canada and China. Canada led as the country to which most exports were shipped, followed by Japan and China. 
Figure 8. Country of Origin \& Destination

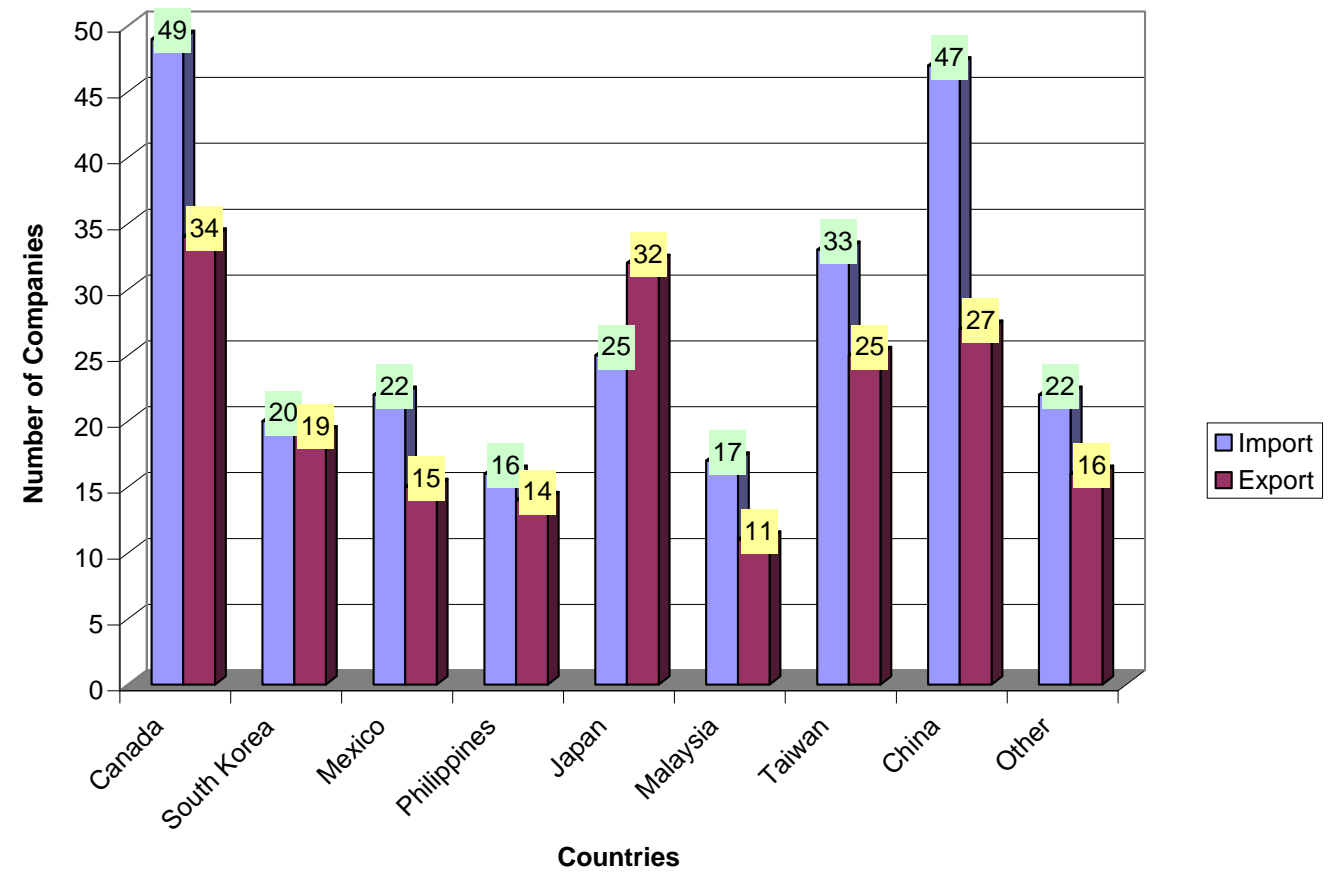

Respondents were also asked to specify the type of products that are imported and exported at their facility. The graph in Figure 9 includes eleven product type categories previously indicated and the number of companies that distribute them. As was done with Figure 4, an 'Others' category was included for any products that did not fall under the ten categories. Items contained in the 'Other' category were random personal effects and packaging materials.

Thirty-three of 142 survey respondents listed general merchandise as the type of items they imported, making it the most common category shipped to Washington's warehouses and distribution centers. This category was also the one most commonly listed for exports as well with 19 of 142 distributors. Industrial products and food and grocery products were the next two largest import categories with 18 and 19 distributors handling each product type respectively. Paper and lumber along with frozen foods lead for largest exported products.

The distribution percentages of imported and exported shipments by mode type are shown in Figure 10. A large percentage of imports and exports are being transported via Ocean-Truck. The Truck only category accounts for roughly $40 \%$ of the distribution of imported and exported goods along Washington's highways. The other four modes made up the remaining $10 \%$ for imports and $20 \%$ for exports. For both imported and exported shipments, only an estimated five percent travel by rail. The Air-Truck and Rail-Truck modes were significantly lower. The percentages of shipments that are destined for export via Truck-Barge were almost equivalent to that of Rail. Most of these are container shipments bound for various seaports along the Northwest coast.

\section{OTHER TRANSPORTATION RELATED ISSUES}

Respondents ranked transportation issues in relation of importance to their business. The scale ranged from 0 being no problem to 5 being a major problem. Approximately $71 \%$ of all respondents ranked transportation costs as being either a 4 or 5 . Over half of these respondents ranked this issue as a 5, believing it to be the most important issue affecting their business. Two-thirds of all respondents ranked scheduling as the next issue of importance. Congestion came in third, with just over half of the respondents ranking it as an issue of high importance. 
Figure 9. Type of Imported \& Exported Products

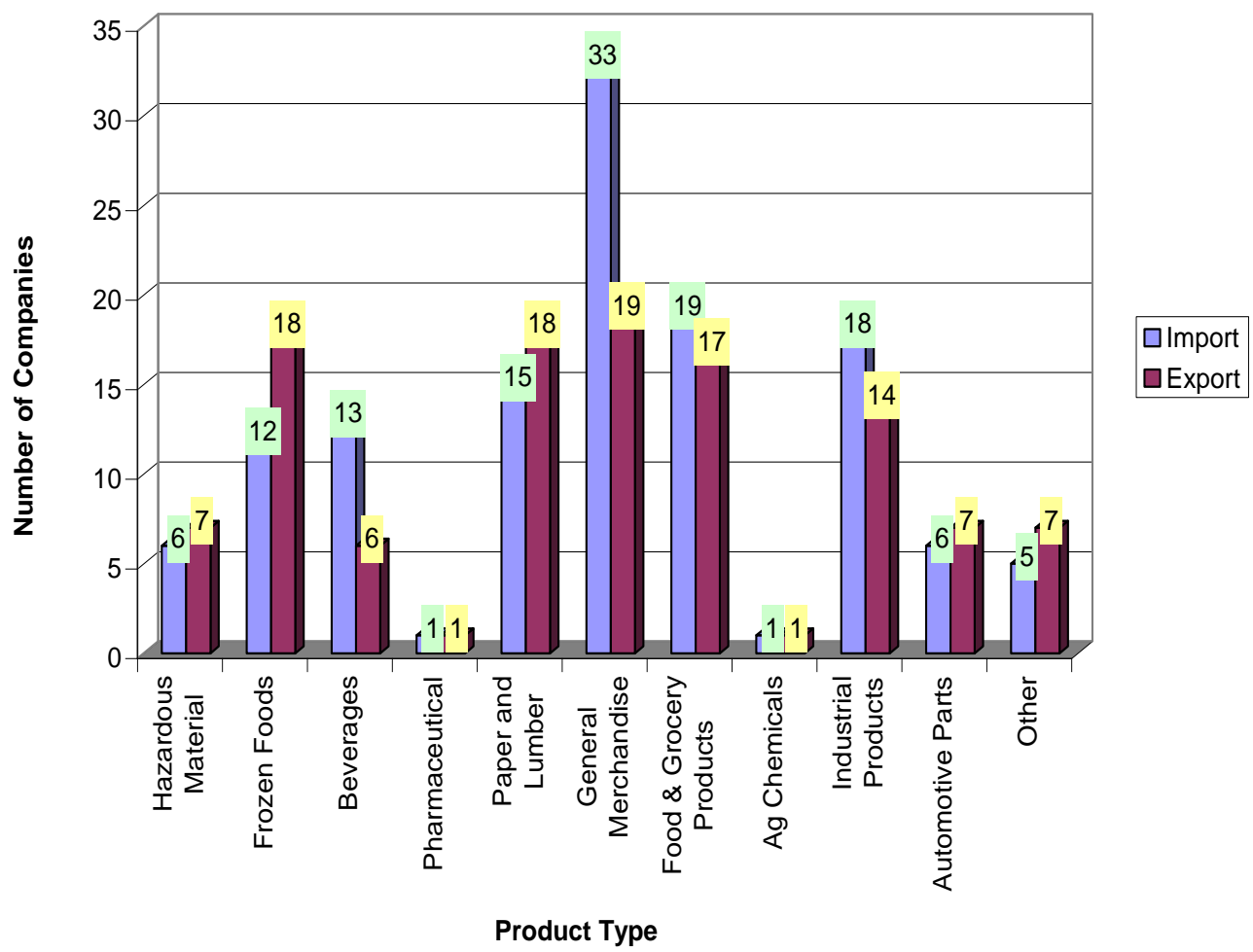

Figure 10. Import/Export Mode of Shipment

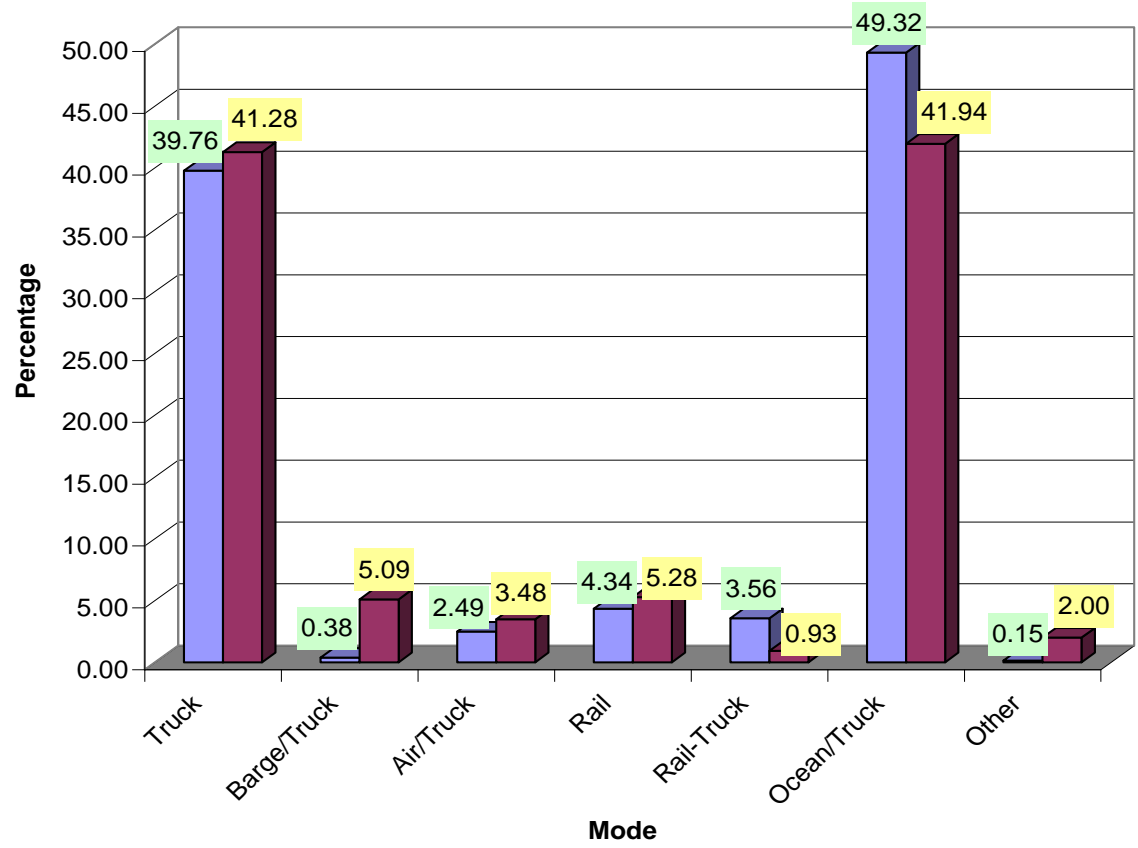


Seasonal road closures were most commonly identified as not being a problem at all. Over $60 \%$ of the companies ranked this issue between the ranges of 0 and 3. Approximately $50 \%$ of respondents ranked weight restrictions and state regulations as being no problem to somewhat of a problem. Nearly a third of them ranked these two issues as being somewhat of a problem.

Figure 11. Ranking of Transportation Issues in Relation of Importance

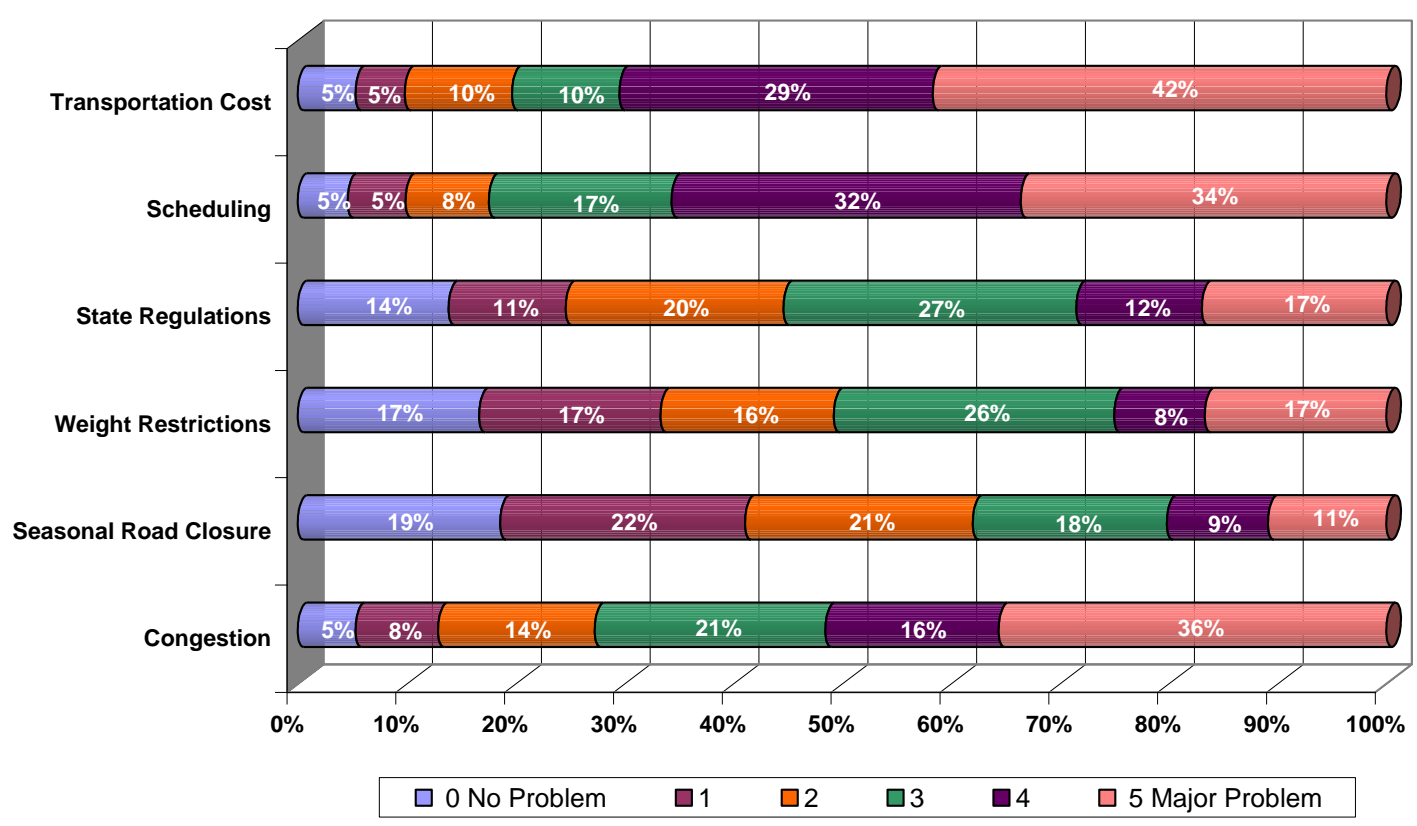

To determine if there is a difference in the ranking of issues throughout the state, responses were separated into eastern and western Washington categories. The eastern Washington category is made up of Spokane, I-82, and I90 regions. Western Washington consists of the Puget Sound, I-5 North and I-5 South regions.

Nearly half of all respondents in the eastern region rank transportation costs as being a major problem affecting their business. Eighty-one percent of respondents ranked this issue as either a 4 or 5. Scheduling was the next issue of importance for distributors in this region. Thirty-eight percent of respondents ranked the issue as a 5 , with another $36 \%$ ranking it a 4 .

The biggest concern for western Washington companies is congestion. Approximately $60 \%$ of respondents indicated congestion as being either a considerable or major problem. Forty-eight percent of respondents ranked the issue as a 5, the highest percentage among the six issues. In addition, another $22 \%$ of respondents ranked the same issue as being somewhat a problem.

Respondents also identified the type of freight chokepoints, whether physical, regulatory, social, or institutional that they would like to see eliminated. Evidently, there was a great concern among those in the industry over the continual rise in fuel costs. Most respondents in each of the six regions identify a particular highway or route where congestion or bottlenecks typically occur. Two regions identified new regulations limiting driver times as being a major chokepoint. In addition, two regions indicated a desire to see a decrease in DOT regulations. Weigh station checkpoints were of significant concern to one region. Other problems or concerns identified in this study pertain to rising transportation costs, city/fuel tax increases, and an exorbitant amount of roadwork. 
Table 1: Statewide Chokepoints

\begin{tabular}{|c|c|c|}
\hline Type of Chokepoints & Chokepoint Effects & Other Issues \\
\hline $\begin{array}{l}\text { Federal/State Regulations: } \\
\text {-Hours of Service } \\
\text {-Driver Regulations } \\
\text {-Class B License } \\
\text {-Security/Customs } \\
\text {-Fuel and City B\&O } \\
\text { Tax } \\
\text { Congestion: } \\
\text {-I-5 and I-405 } \\
\text {-SR-167 Southbound } \\
\text {-SR-392/I-2 } \\
\text { Interchange } \\
\text {-Hwy-12 } \\
\text { Weight Restrictions: } \\
\text {-Inconsistency on } \\
\text { Interpretation of Rules } \\
\text { and Regulations at Weight } \\
\text { Stations } \\
\\
\text { Transportation Costs: } \\
\text {-Longshoreman Strike } \\
\text {-Increased Labor Rates } \\
\text {-Fuel Tax } \\
\text {-Rail Cost and } \\
\text { Availability } \\
\text { Seasonal Road Closures: } \\
\text {-Snoqualmie Pass } \\
\text {-Portland to Tri-Cities } \\
\end{array}$ & $\begin{array}{l}\text { Federal/State Regulations: } \\
\text {-Increased Labor Costs } \\
\text {-Impeded Delivery Time } \\
\text {-Increased Transportation Costs } \\
\text {-Slowdown of Freight } \\
\text { Movement } \\
\text {-Increased Operating Costs } \\
\text { Congestion: } \\
\text {-Excess Delays/Turnaround Time } \\
\text {-Slowdown of Freight } \\
\text { Movement } \\
\text {-Lost Productivity } \\
\text {-Increased Freight Volume } \\
\\
\text { Weight } \\
\text { Restrictions: } \\
\text {-Restricted Growth Opportunities \& } \\
\text { Business Activity } \\
\text {-Increased Operating Costs } \\
\text {-Operation/Labor Overtime } \\
\text {-Delays/Missed Appointments } \\
\text { Transportation Costs: } \\
\text {-Impeded Delivery Time/ } \\
\text { Productivity Loss } \\
\text {-Increased Labor Costs } \\
\text {-Increased Transportation Costs } \\
\text {-Market Access } \\
\text { Seasonal Road Closures: } \\
\text {-Route Access/Operating Time } \\
\text {-Increased Transportation Costs } \\
\text {-Slowdown of Freight } \\
\text { Movement } \\
\text { Tow }\end{array}$ & $\begin{array}{l}\text {-Increased Fuel Costs } \\
\text {-Poor Roadway Conditions } \\
\text {-Rail Congestion and } \\
\text { Availability } \\
\text {-Border Crossing/Trade } \\
\text { Problems } \\
\text {-Current Infrastructure vs. } \\
\text { Growth } \\
\text {-Port Terminal Access } \\
\text {-Freight Only Lanes } \\
\text {-Equipment Availability } \\
\text {-Environmental Regulations }\end{array}$ \\
\hline
\end{tabular}

\section{CONCLUSION AND RECOMMENDATIONS}

A wealth of unprecedented data was obtained from the Warehouse/Distribution Center study. Analysis of this data provides further insight and understanding into how Warehouse/ Distribution Centers operate and how they utilize transportation. Data pertaining to the hours of operation, facility size, and type of products handled provide a snapshot view of the characteristics associated with the Warehouse/Distribution Center industry in Washington.

Furthermore, the collection of data pertaining to the national and international movement of freight indicates the type of investment needed to maintain economic vitality of this industry within the state of Washington. The responses to the ranking of transportation issues and feedback on other transportation related issues were also very useful in identifying the type of chokepoints and system deficiencies that occur in various freight corridors throughout the state.

In order to disseminate the wealth of data collected in this study further, additional analysis will occur in the months to come. However at this time, based upon the findings obtained from the Warehouse/Distribution Center study, the authors offer the following recommendations: 
- To ensure efficient freight mobility, transportation agencies should investigate methods that will promote the scheduling of freight shipments during off-peak hours in heavily congested corridors.

- Transportation agencies should also consider employing all regional freight corridor maps generated from this and other recent industry studies prepared by SFTA in identifying future infrastructure developments needed to alleviate heavily congested corridors within Washington.

- $\quad$ Statewide, transportation costs were indicated as the leading transportation problem among distributors in this industry. Additional analysis is needed to determine the different types of variable and fixed costs that are associated with this issue.

- New driver time regulations were also indicated as a critical issue affecting warehouse/distribution centers. Analysis is recommended to determine the overall impact these regulations will have upon the industry.

- To encourage and facilitate international trade, agencies are recommended to investigate the type of problems encountered by warehouse/distribution centers to effectively distribute freight to and from the Port of Entry and beyond.

\section{NOTES}

